\title{
Prevention of Sexually Transmitted Diseases (STDs) The Islamic Perspective
}

\author{
Mahmoud A. Ismail, M.D.*, Jamal A. Said, B.A. \\ Chicago, Illinois
}

DOI: http://dx.doi.org/10.5915/20-3-13285

\begin{abstract}
Recently, sexually transmitted diseases (STD's) became the topic of discussion not only in medical journals and social circles, but in Newsweek and Time magazines, and on television shows night and day. These diseases have medical as well as social ramifications. Syndromes, and end results of these diseases include: death due to Acquired Immunne Deficiency Syndrome (AIDS), infertility due to Pelvic Inflammatory Disease (PID), increased ectopic pregnancies due to increased incidence of salpingitis. Men who are sexual partners of infected women develop urethritis, epididymitis, as well as prostatitis and decreased fertility. Newborns of affected mothers develop conjunctivitis and pneumonia as well as respiratory syndromes. Children of mothers infected with herpes genitalis may develop the same infection and some of them will die of systemic herpetic infection. Patients are advised by their physician to avoid having more than one sexual partner, especially if they are wearing an Intra-uterine contraceptive device (I.U.D.) since it has been proven beyond doubt that multiple sexual partners is a risk factor for developing infection followed by infertility in women in general, and in those using I.U.D.'s for contraception, in particular. The current cost of such infections to the economy of the U.S.A. is unknown. The estimated cost is 3 billion dollars for PID only, including both direct and indirect costs.

The sexual revolution caused an epidemic of such diseases and all their sequelae with all the frightening complications of these infections, especially death. The pendulum is moving again to conservatism and the flames of the sexual revolution are fading, being replaced by the light of good reason and good health. Islamic moral laws, if adopted, would have prevented STDs and their devastating effects.
\end{abstract}

Key words: Sexually transmitted diseases, prevention, social sequelae, Islamic laws.

More than twenty different sexually transmitted diseases (STD's) are recognized now in the U.S.A. and around the world. These diseases are transmitted primarily during sexual contact. The social, health and financial implications of such infections are tremendous. Sexual partners are inflicted with diseases that cause either acute health emergencies in both males e.g.: epididymitis, and females e.g.: salpingitis, ectopic pregnancies, or long lasting complications e.g.: infertility, chronic pain, recurrent herpetic infections and chronic hepatitis, or can lead to terminal illness and death in the patients and their offspring. STD's are the direct cause of immense finan-

From the Department of Obstetrics and Gynecology,

The University of Chicago,

and the Mosque Foundation of Greater Chicago,

Reprint requests: Mahmoud A. Ismail, M.D.,

Department of Obstetrics and Gynecology,

The University of Chicago,

5841 S. Maryland Ave.,

Chicago, IL. 60637 cial burden on individuals, families, and society at large. In the U.S.A. alone, the annual expenditures for the direct care of STD's patients exceed \$2 billion, and estimates for the direct care of gonorrhea and Pelvic Inflamatory Disease (PID) patients exceed $\$ 1$ billion each year.' An alarming number of heterosexual young women develop PID. It has been calculated that up to $3 \%$ of the sexually active teenage women develop PID every year. ${ }^{2}$ STD's prevention has mainly been focused on and directed to the areas of health education, disease detection, optimal treatment, partner tracing, patient counseling, clinical services, training and research. ${ }^{3}$

Islamic teaching could have saved society all the troubles of these diseases, syndromes and their sequelae by regulating the sexual relationships between members of the society. Islam prohibits premarital sexual relationships and permits sexual relation only between married couples and within the boundaries revealed by Allāh in the Glorious Qur'ān as follows:

"And who guard their modesty-Save from their wives or that their right hands possess, for then they 
Table 1. Risk factors for developing Pelvic Inflamatory Disease

- Teenager (Ages 10-19)

- Multiple sexual partners

- IUD contraception

- Previous diagnosis of PID

- Sexual consort with urethritis

- Sexual consort with gonorrhea

- Endocervix positive for Neisseria gonorrhoeae and or Chlamydia trachomatis

- Sexual intercourse during menstruation

are not blameworthy. But whoso craveth beyond that, such are transgressors"'.4,5

In this paper we will address PID in some detail and mention other sequlae of STD's in more general terms.

\section{Pelvic inflammatory disease}

This disease includes endometritis, salpingitis and peritonitis. Microbiologocal causes differ according to different geographic areas. Neisseria gonorrhoeae accounts for $10-66 \%$ of PID etiology in the U.S.A. Chlamydia trachomatis is linked to $20 \%$ of such infections. ${ }^{6}$ Other cervical/vaginal organisms including aerobes, anaerobes and mycoplasmas play important roles in the pathogenesis of PID even in the presence of N. gonorrhoeae and/or chlamydia." There are several risk factors for developing PID. (table 1).

A. Menses: It has been known that $60-75 \%$ of cases of PID occur within one week of menses. Menses predispose the onset and spread of infection in several possible ways: a) the absence of the cervical mucous plug, which has antibacterial activity and probably limits the ascent of micro-organisms through the cervical canal. b) the presence of the raw surface area of the endometrium after the sloughing that occurs during menses. c) the availability of blood which is an excellent medium for bacterial growth and multiplication. Sweet et $\mathrm{al}^{8}$ has reported that during menses certain morphological changes occur in the cervical Niesseria gonorrhoeae organism. The organism is changed to a more pathogenic form that causes salpingitis and peritonitis. All the above factors make the monthly period of menstruation the most vulnerable time for acquiring infection. It is no wonder that Islamic teachings prohibit sexual intercourse during menses. Allāh says in the Glorious Qur'ān.

"They question thee (O Muhammad) concerning menstruation. Say: It is an illness, so let women alone at such times and go not in unto them till they are cleaned. And when they have purified themselves, then go in unto them as Allāh hath enjoined upon you. Truly Allāh loveth those who turn unto Him, and loveth those who have a care for cleanness."

B. Multiple sexual partners: Industrial societies are reaping the consequences of the sexual revolution that had swept the Western hemisphere in the last two decades. STD's have become the leading diseases of the decade, and their complications and sequelae are on the rise. The increased number of sexual partners to more than 2-3 partners in a 6 month period has been identified as a risk factor in developing PID as well as primary infertility. ${ }^{10}$ Such a risk factor has been further investigated by multiple authors to explain the pathophysiology and the reasoning for such risk. Whether the exposure to many males would expose a woman to multiple pathogenic organisms or whether it affects the local immunity in her lower genital tract is not clear. Exposure to a sexual partner with either gonorrhea or chlamydia trachomatis urethritis has been considered a risk factor for developing PID. ${ }^{11}$ Women who are divorced or separated have suffered more often from PID than single, married or widowed women possibly due to promiscuity. ${ }^{12}$ Teenage women have a higher incidence of PID possibly due to multiple sexual partners, lack of medical attention and lack of antibodies to combat infection.

C. Intrauterine contraceptive devices (IUDs): ancient Arab tradesmen used to prevent pregnancies in their female camels during their trips by inserting small stones inside their uterine cavities. That old medical practice is the basis of the current theories behind intrauterine contraceptive devices' usage. Although these devices are effective in preventing pregnancies, their use has been a major risk factor in the development of PID. Such complications and the litigation that arose due to their use has prompted the manufacturing companies to pull such devices off the market. The pathophysiology of the increased risk of infection associated with the presence of such devices is summed up in the fact that such foreign bodies in the uterine cavity, with thin multifilamentous tails hanging through the cervical canal into the vagina, cause pathogenic bacteria from the vaginal flora to ascend through the cervix into the endometrial cavity, and hence to the endosalpinx where infections ensue and cause the whole syndrome of PID to develop. ${ }^{13}$

\section{Diagnosis}

Diagnostic criteria for Pelvic Inflammatory Disease were defined by Hager et al. ${ }^{14}$

(table 2) Differential diagnosis of PID include ${ }^{15}$ 
Table 2. Diagnostic criteria for Pelvic Inflammatory Disease $^{14}$

Direct abdominal tenderness with or without rebound tenderness,

Tenderness on cervical motion,

Uterine tenderness,

Adnexal tenderness,

Combined with one or more of the following:

Temperature $38^{\circ} \mathrm{C}\left(100.4^{\circ} \mathrm{F}\right)$

Leukocyte count $10^{4} / \mathrm{mm}^{3}$

Gram-negative intracellular diplococci in endocervical smear

Leukocytes in peritoneal fluid recovered by culdocentesis or laparoscopy

Pelvic inflammatory mass or abscess diagnosed by physical examination or sonography

Table 3. Outpatient therapy for acute, uncomplicated Pelvic Inflammatory Disease as recommended by the Centers for Disease Control ${ }^{16}$

Non-penicillin-allergic patients

After $1 \mathrm{~g}$ probenecid orally:

Amoxicillin, $3 \mathrm{~g}$ orally, or

Ampicillin, $3.5 \mathrm{~g}$ orally, or

Aqueous procaine penicillin $\mathrm{G}, 4.8$ million units intramuscularly, or

Cefoxitin, $2 \mathrm{~g}$ intrtamuscularly

Ceftriaxone or equivalently effective cephalosporin

Penicillin-allergic patients

Spectinomycin, $2 \mathrm{~g}$ intramuscularly, or

Tetracycline loading dose plus maintenance doses consisting of a seven-day course of:

Tetracycline, $0.5 \mathrm{~g}$ four times a day, or

Doxycycline, $0.1 \mathrm{~g}$ twice a day, or

Erythromycin base, $0.5 \mathrm{~g}$ four times a day, or

Erythromycin stearate, $0.5 \mathrm{~g}$ four times a day, or

Erythromycin ethylsuccinate, $0.8 \mathrm{~g}$ four times a day

leiomyomata uteri, ectopic pregnancy, twisted ovarian cyst, ruptured adnexal masses, acute appendicitis, pelvic endometriosis, mensenteric lymphadenitis, inflammatory bowel disease, pelvic congestion, as well as normal pelvis.

\section{Management}

Tables 3 and 4 explain the therapeutic modalities as recommended by the Centers for Disease Control (CDC) for both outpatient and inpatient manage-
Table 4. Inpatient therapy for Pelvic Inflammatory Disease as recommended by the Centers for Disease Control $^{16}$

Regimen A

Cefoxitin, $2.0 \mathrm{~g}$ intravenously every six hours

Doxycycline, $0.1 \mathrm{~g}$ intravenously every 12 hours

Doxycycline, $0.1 \mathrm{~g}$ by mouth every 12 hours for six to ten days

Regime B

Clindamycin, $0.6 \mathrm{~g}$ intravenously every six hours Gentamicin

$2 \mathrm{mg} / \mathrm{kg}$ intravenously, loading dose

$1.5 \mathrm{mg} / \mathrm{kg}$ intravenously every eight hours

Clindamycin, $0.45 \mathrm{~g}$ by mouth every six hours for six to ten days

ment. ${ }^{16}$ The majority of medical centers adhere to such recommendations or may alter certain antibiotics to cover certain organisms possibly anaerobes as well as chlamydia trachomatis. ${ }^{17-20}$

\section{Concluding remarks}

The economic cost of the STD's is enormous. ${ }^{21,22}$ Such viral and bacterial infections are causing a heavy burden on the society in the financial, social and medical fields. ${ }^{23}, 24$. Human immunodeficiency viral infection (AIDS) is causing a spectrum of diseases and syndromes that end by death. ${ }^{25,26}$ Sexually transmitted diseases has become an international concern as well as a problem. Health professionals from all over the world meet on a yearly basis to discuss topics of international concern such as PID and AIDS. Western governments are allocating more money and more efforts for research in these areas both in diagnosis and prevention. The magnitude of the problem has been accurately predicted by Prophet Muhammad (PBUH) in a Hadith ${ }^{27}$

"Any group of people, where corruption has spread between them; without advising each other to avoid it, will experience diseases and infections that have not been known to their predecessors."

Adherence to Islamic moral laws would be the most effective, it not the only effective way to interrupt the transmission of STD's and will save humanity from these diseases and their serious consequences.

\section{References:}

1. Wiesner PJ, Parra WC: Sexually transmitted diseases: Meeting the 1990 objectives-a 
challenge for the 1980 's. Public Health Rep 1982; 97:409.

2. Bell TA, Holmes KK: Age specific risks of syphilis, gonorrhea, and hospitalized pelvic inflammatory disease in sexually experienced US women. Sex Transm Dis 1984; 11:291.

3. Cates W Jr., Parra WC, Brown ST: Control of sexually transmitted diseases: View from the United States of America. Br J Vener Dis 1984; $60: 322$.

4. Glorious Qur'ān, Chapter 23, verses 5-7.

5. Glorious Qur'ān, Chapter 70, verses 29-31.

6. Stamm WE, Guinan ME, Johnson C, et al: Effect of treatment regimens for Neisseria gonorrhoeae on simultaneous infection with Chlamydia trachomatis. N Engl J Med 1984; 310:545.

7. Eschenbach DA, Holmes KK: The etiology of acute pelvic inflammatory disease. Sex Transm Dis $1979 ; 6: 224$.

8. Sweet RL, Mills J, Hadley KW, et al: Use of laparoscopy to determine the microbiologic etiology of acute salpingitis. Am J Obstet Gynecol 1979; 134:68.

9. Glorious Qur'ān, Chapter 2, verse 222.

10. Daling JR, Weiss NS, Metch BJ, et al: Primary tubal infertility in relation to the use of an IUD. N Engl J Med 1985;312:937-941.

11. Thelin I, Mardh P A: Contact tracing in genital Chlamydia infection. Scand J Infect Dis (suppl) 1982; 32:163.

12. Jones OG, Zaidi AA, St. John RK: Frequency and distribution of salpingitis and pelvic inflammatory disease in short-stay hospitals in the United States. Am J Obstet Gynecol 1980; 138:905.

13. Westrom L, Bengtsson LP, Mardh P A: The risk of pelvic inflammatory disease in women using intrauterine contraceptive devices as compared to non-users. Lancet $1976 ; 2: 221$.

14. Hager WD, Eschenbach DA, Spence MR, et al: Criteria for diagnosis and grading of salpingitis. Obstet Gynecol 1983; 61:113.

15. Jacobsen L: Differential diagnosis of acute pelvic inflammatory diesase. Am $\mathrm{J}$ Obstet Gynecol 1980; 138:1006.

16. Sexually transmitted diseases. Treatment guidlines, 1985. MMWR (suppl) 1985; 34:92S.

17. Thompson SE, Brooks, C, Eschenback DA, et al: High failure rates in outpatient treatment of salpingitis with either tetracycline alone or pencillin/ampicillin combination. Am J Obstet Gynecol 1985; 152:635.

18. Cunningham FG, Hauth JC, Strong JD, et al: Evaluation of tetracycline or pencillin and ampicillin for treatment of acute pelvic inflammatory disease. N Engl J Med 1977; 296:1380.

19. Thompson SE: Treatment of pelvic inflammatory disease. Am J Obstet Gynecol 1980; 138:588.

20. Grimes DA, Blount JH, Patric J, et al: Antibiotic treatment of pelvic inflammatory disease: Trends among private physicians in the United States, 1966 through 1983. JAMA 1986; 256:3223.

21. Curran JW: Economic consequences of pelvic inflammatory disease in the United States. Am J Obstet Gynecol 1980; 138:848.

22. Chlamydia trachomatis infection: Policy guidelines for prevention and control. MMWR (suppl) $1985 ; 34: 53 \mathrm{~S}$.

23. Washington AE, Johnson RE, Sanders LL Jr: Chlamydia trachomatis infections in the United States: What are they costing us? JAMA 1987; 257:2070.

24. Surgeon General's Report on Acquired Immune Deficiency Syndrome. JAMA 1986; 256:2784-2789.

25. Francis DP, Chin J: The Prevention of Acquired Immune Deficiency Syndrome in the United States. JAMA 1987; 257:1357-1366.

26. Noorwali, AA, Elawad, AAR: AIDS: The role of Islamic sexual rules in prevention. JIMA 1987; 19:88.

27. Sunnan Ibn Mājah, Book of Tumult (Bāb alFitan), vol 2, p 1333, number 22, Muḥammad Fu'ād 'Abdul Bāqī, editor, 'İsā al-Bābì al-Ḥalabi publishing Company, Cairo, Egypt. 